\title{
Carriage of group D streptococci in the human bowel
}

\author{
C. J. NOBLE
}

From the Area Public Health Laboratory, Dulwich Hospital, East Dulwich Grove, London SE22 8 QF, UK

SUMMARY Sixty faecal samples, 39 from adults and 21 from neonates, were investigated by means of a simple scheme to isolate and identify any group D streptococci present. A number of differences were found between the two groups. Group D streptococci were absent from $43 \%$ of the neonates compared with only $13 \%$ of the adults; Streptococcus bovis was commoner in the neonates $(23.8 \%)$ than in the adults (5\%), and Streptococcus faecium was not isolated from any of the infant samples although it was common in the adult samples (25\%). The viable counts of Strep. faecium were found to be, on average, 100-fold lower than those of Streptococcus faecalis.

The methods and results are discussed with reference to the clinical significance of group D streptococci, especially in bacterial endocarditis and carcinoma of the colon.

Group D streptococci form part of the normal gut flora of man and animals, but the distribution of the various species within the group is still imperfectly understood (Medrek and Barnes, 1962). Most studies show that Streptococcus faecalis and Streptococcus faecium are common human gut commensals, while Streptococcus bovis and other species are less frequently present. Recently, attention has been focused on Strep. bovis, which has been shown to be an important cause of endocarditis. In a three-year study of streptococcal isolates, Parker and Ball (1976) showed that Strep. bovis was associated with $17 \cdot 3 \%$ of 317 cases of endocarditis, and that in the over-55 age group this organism was associated with nearly onequarter of the cases.

More recently, Klein et al. (1977) have shown that the incidence of gut carriage of Strep. bovis is greatly increased in patients with carcinoma of the colon. Gross et al. (1975) devised a relatively simple scheme for identifying and speciating group D streptococci, which was shown by Facklam (1976) to give an accuracy of speciation of $98.5 \%$ in one large series.

The present study is an investigation of group D streptococci isolated from faecal samples from three groups of patients-hospital neonates, adult inpatients, and adult outpatients-at Dulwich Hospital. The streptococci were identified by means of

Received for publication 31 May 1978 the above-mentioned scheme, and viable counts were performed.

\section{Material and methods}

Sixty faecal samples were examined: 21 were obtained from hospital neonates aged 6-7 days, 10 from adult inpatients, and 29 from adult outpatients.

The transit time for domiciliary specimens was a maximum of five hours, but hospital specimens were received more promptly. On arrival in the laboratory all specimens were refrigerated at $4^{\circ} \mathrm{C}$ and processed within three hours. A pea-sized lump of each sample was placed in a weighed sterile container of glycerol broth, homogenised on a vortex mixer, and stored for up to one month at $-20^{\circ} \mathrm{C}$. Frozen specimens were thawed at room temperature, and serial dilutions were made in 9 Ringer's solution up to a dilution of $10^{-4}$ (Hewitt and Rigby, 1976). All the dilutions were immediately inoculated on to $M$. enterococcus Agar, a selective medium for group D streptococci (Becton, O Dickinson \& Co Ltd) in 0.1-ml volumes, by means $N$ of Pasteur pipettes calibrated to deliver $0.02 \mathrm{ml} \underset{\mathrm{N}}{\mathrm{N}}$ drops, and were spread with a glass rod. All dilution plates were incubated aerobically at $37^{\circ} \mathrm{C}$ for $c$ 48 hours when counts of each colonial type were $\frac{\widetilde{D}}{\mathbb{N}}$ made at the most convenient dilution. The minimum count detectable with this system is 100 organisms $T$ per gram of faeces. Counts were made on the 
assumption that each sample weighed $1 \mathrm{~g}$, and a correction was made later for the actual weight of sample taken.

Single colonies were picked and inoculated on Horse Blood Agar plates (Oxoid) for purity. Subcultures were made from the pure cultures on to $40 \%$ bile aesculin slopes (prepared in the laboratory from Oxoid constituents) and to Robertson's Cooked Meat Broths (laboratory prepared from Lab M constituents).

Strains that grew on $40 \%$ bile aesculin, blackened the medium after 48 hours' incubation, were catalase-negative, and were Gram-positive oval cocci in pairs or chains in broth culture, were presumed to be group D streptococci and were submitted to further tests. Strains that failed to satisfy these criteria were discarded. All isolates were tested for their ability to (1) utilise pyruvate, (2) hydrolyse arginine, and (3) grow in 6.5\% sodium chloride broth. The scheme of identification is set out in the Figure and is that described by Gross et al. (1975) and Facklam (1974).

UTIJ.ISATION OF PYRUVATE

Formula of medium:

Difco yeast extract $2.5 \mathrm{~g}$

Difco tryptone $5.0 \mathrm{~g}$

Dipotassium hydrogen phosphate $2.5 \mathrm{~g}$

Sodium of pyruvate salt $5.0 \mathrm{~g}$

Bromothymol blue $0.02 \mathrm{~g}$

Agar $6.0 \mathrm{~g}$

Distilled water $500 \mathrm{ml}$.

The medium was prepared as a slope in a bijou bottle. A positive reaction was indicated by the development of a yellow coloration after 48 hours' incubation at $37^{\circ} \mathrm{C}$ (Facklam, 1976).

\section{SALT TOLERANCE}

Five millilitres of broths containing $6.5 \%$ sodium chloride were inoculated heavily and incubated at $37^{\circ} \mathrm{C}$ for 48 hours. They were examined for turbidity with the naked eye; broths that were not turbid were Gram stained and, if no organisms were seen, the test was repeated (Cowan, 1974).

\section{HYDROLYSIS OF ARGININE}

Ammonia production was indicated by the development of a brown coloration on the addition of $0.25 \mathrm{ml}$ of Nessler's Reagent to $5 \mathrm{ml}$ of medium after five days' incubation at $37^{\circ} \mathrm{C}$ (method of Niven et al. (1942), see Cowan (1974)).

In addition to the tests described above, carbohydrate fermentation tests were performed on those isolates thought to be either Strep. faecium or Strep. bovis. Hiss' $1 \%$ Serum Sugars with Andrade's Indicator were inoculated and incubated for 48

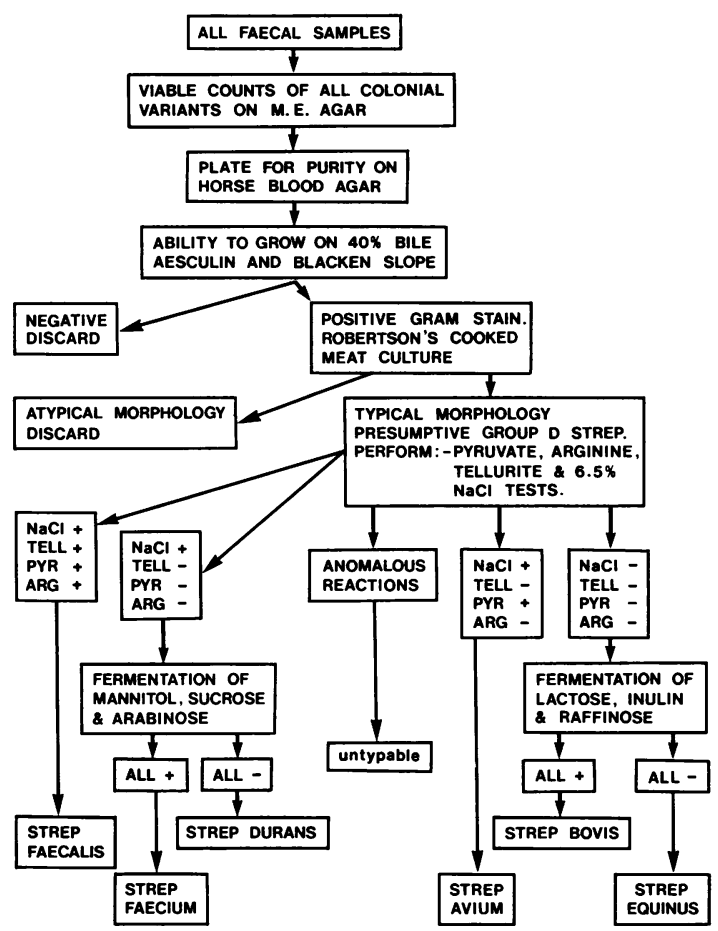

Figure Scheme for identifying and speciating group $D$ streptococci.

hours at $37^{\circ} \mathrm{C}$. Fermentation of mannitol, sucrose, and arabinose distinguishes Strep. faecium from Strep. faecium var durans, and fermentation of lactose, inulin, and raffinose distinguishes Strep. bovis from Streptococcus equinus.

Finally, all the presumptive group D isolates were submitted to Lancefield grouping. The isolates were cultured in $50-\mathrm{ml}$ volumes of glucose broth (Southern Group Laboratory) at $37^{\circ} \mathrm{C}$ for 18 hours. The supernatant was removed and the deposit autoclaved to extract the group D antigen (Hamilton, 1972). Group D antiserum was obtained from Wellcome Biological Reagents, Beckenham, Kent. Precipitation tests were performed by the layering method (Williams, 1958) in capillary tubes, and positive reactions occurring within five minutes were recorded. Extracts that failed to group were retested at a dilution of 1 in 2,1 in 4 , and 1 in 8 in order to overcome any prozone effect due to antigen excess. A minority of isolates failed to group by this procedure and were submitted to counter-current immunoelectrophoresis by the method of McIntyre (1978).

A number of lyophilised strains of group D streptococci were obtained from the National 
Table 1 List of control strains

\begin{tabular}{ll}
\hline NCTC strains & \\
\hline 8133 & Strep. bovis \\
8307 & Strep. faecium var durans \\
775 & Strep. faecalis \\
2705 & Strep. faecalis var liquefaciens \\
5957 & Strep. faecalis var zymogenes \\
7171 & Strep. faecium \\
\hline Streptococcal Reference & Laboratory strains \\
\hline A & Strep. bovis \\
B & Strep. faecalis \\
C & Strep. faecium \\
D & Strep. bovis \\
\hline
\end{tabular}

Collection of Type Cultures and some further isolates from the Streptococcal Reference Laboratory. These strains were used to provide positive and, where appropriate, negative controls for the biochemical tests (Table 1).

\section{Results}

All the control strains were tested alongside the faecal isolates and gave appropriate results for (1) hydrolysis of aesculin in $40 \%$ bile, (2) tolerance of $6.5 \%$ sodium chloride, (3) pyruvate reduction, and (4) arginine hydrolysis. One control Strep. bovis failed to ferment inulin on repeated testing. Serological grouping was performed with the following results:

Number of strains tested 5 controls

46 faecal strains

Group D status

Confirmed

43 confirmed

Three faecal isolates failed to group with the D antiserum by precipitation or immunoelectrophoresis.

On the basis of the scheme described under Material and methods, isolates were speciated into Strep. faecalis, Strep. faecium, Strep. avium, Strep. bovis, and Strep. equinus. No Strep. faecium var durans was isolated, and strains that could not be identified by this method were classified as unidentified group D streptococci.
Table 2 shows the relative frequency of isolation ${ }^{D}$ of the various species of group D streptococci $\vec{F}$ from the three groups of patients, and Table 3 을 shows the distribution of viable counts in the $43 \underset{\overrightarrow{\mathrm{F}}}{\overrightarrow{\mathrm{C}}}$ specimens examined. The viable counts for the neonates and adult groups are combined, as insufficient data are available for separate tables.

One or more species of group D streptococci $\frac{\sigma}{\sigma}$ were isolated from 46 of the 60 samples studied. Seventeen samples yielded two different species, $ڤ$ and two samples yielded three species.

Table 4 shows the selectivity of $M$. enterococcus Agar for group D streptococci.

Table 3 Viable counts of various species of group D streptococci from all groups of patients (expressed as organisms per gram of faeces)

\begin{tabular}{llllllllll}
\hline Species & $\begin{array}{l}\text { No. of isolates falling in each } \\
\text { log range }\end{array}$ & $\begin{array}{l}\text { No. of samples } \\
\text { studied }\end{array}$ \\
\cline { 2 - 8 } & $10^{8}$ & $10^{7}$ & $10^{6}$ & $10^{5}$ & $10^{4}$ & $10^{3}$ & $10^{2}$ & \\
\hline Faecalis & 1 & 5 & 4 & 5 & 1 & 2 & 1 & 19 \\
Faecium & 0 & 1 & 0 & 3 & 2 & 2 & 2 & 10 \\
Avium & 0 & 0 & 0 & 1 & 1 & 0 & 0 & 2 \\
Bovis & 0 & 1 & 2 & 1 & 0 & 0 & 0 & 4 \\
Equinus & 0 & 0 & 0 & 1 & 1 & 0 & 0 & 2 \\
Unidentified & 0 & 2 & 0 & 1 & 1 & 2 & 0 & 6 \\
\hline
\end{tabular}

NB 1 Strep. faecium not isolated from neonates.

2 Strep. bovis counts all on neonates.

3 Strep. faecalis counts for adults and neonates not significantly different.

Table 4 Selectivity of M. enterocozcus Agar for group D streptococci

Total number of isolates from all specimens

Total number of group D isolates

Total number of non group D isolates

$\%$ of non group $\mathrm{D}$ isolates

\section{Discussion}

A variety of group D streptococci may be isolated from human faeces (see Table 2). In this study, one or two species were commonly isolated from a

Table 2 Species of group D streptococci isolated from faeces of hospital neonates, adult inpatients, and adult outpatients

\begin{tabular}{|c|c|c|c|c|c|c|c|c|}
\hline \multirow{2}{*}{$\begin{array}{l}\text { Patient } \\
\text { group }\end{array}$} & \multirow{2}{*}{$\begin{array}{l}\text { No. of faeces } \\
\text { examined }\end{array}$} & \multicolumn{7}{|c|}{ No. of faecal specimens containing various species of group D streptococci } \\
\hline & & $\begin{array}{l}\text { Strep. } \\
\text { faecalis }\end{array}$ & $\begin{array}{l}\text { Strep. } \\
\text { faecium }\end{array}$ & $\begin{array}{l}\text { Strep. } \\
\text { avium }\end{array}$ & $\begin{array}{l}\text { Strep. } \\
\text { bovis }\end{array}$ & $\begin{array}{l}\text { Strep. } \\
\text { equinus }\end{array}$ & $\begin{array}{l}\text { Not } \\
\text { identified }\end{array}$ & $\begin{array}{l}\text { Any group } \\
\text { strep. }\end{array}$ \\
\hline Neonates & 21 & $\begin{array}{l}10 \\
(47 \cdot 6)\end{array}$ & 0 & 0 & $\begin{array}{c}5 \\
(23 \cdot 8)\end{array}$ & 0 & $\begin{array}{c}1 \\
(4 \cdot 8)\end{array}$ & $\begin{array}{c}12 \\
(57 \cdot 1)\end{array}$ \\
\hline $\begin{array}{l}\text { Adult } \\
\text { inpatients }\end{array}$ & 10 & $\begin{array}{r}8 \\
(80)\end{array}$ & $\begin{array}{c}3 \\
(30)\end{array}$ & $\begin{array}{c}1 \\
(10)\end{array}$ & 0 & 0 & $\begin{array}{c}1 \\
(10)\end{array}$ & $\begin{array}{c}9 \\
(90)\end{array}$ \\
\hline
\end{tabular}

Percentages are given in parentheses. 
single sample. The predominant species was Strep. faecalis, which was cultured from $53 \%$ of the samples studied. This was followed by Strep. faecium $(25 \%)$ and Strep. bovis $(11 \cdot 6 \%)$. Other group D streptococci were much less common. Thirteen per cent of the samples produced strains that could not be identified by means of the scheme described. Of these eight unidentified strains, all but one belonged to Lancefield group D. Five of them gave a positive arginine reaction but failed to grow in $6.5 \%$ sodium chloride broth or to utilise pyruvate.

In this study, $16 \%$ of all the isolates from $M$. enterococcus Agar were presumed not to be group D streptococci because they failed to blacken bile aesculin medium. The bile aesculin test is a reliable presumptive test of group D status, as shown by Facklam et al. (1974), who tested 920 strains of group D streptococci and found that $99 \%$ blackened the medium. Gross et al. (1975) found that $99.7 \%$ of 844 strains of group D streptococci were bile aesculin positive.

Where mixed cultures of group D and non group $D$ isolates occurred, the presence of the latter did not make counting difficult. All colonial variants were submitted to bile aesculin testing, as it is not possible to distinguish group $D$ streptococci on $M$. enterococcus Agar by colonial morphology alone. These findings are in agreement with those of Pavlova et al. (1972), who found that $18.4 \%$ of their isolates from faeces, sewage, and food samples, plated on M. enterococcus Agar, were not group D streptococci, $6.2 \%$ being either Streptococcus mitis or Streptococcus salivarius. Raibaud et al. (1961) reported overgrowth of lactobacilli when pig caecal samples were plated on this medium.

According to Pavlova et al. (1972), the yield of group D streptococci from faecal samples is less with $M$. enterococcus Agar than with the thalleous acetate medium of Barnes (1956), 3.3 $\times 10^{5}$ organisms per gram as compared with $8.3 \times 10^{6}$ organisms per gram. However, Burkwall and Hartman (1964) found that the range of percent recovery of group D streptococci from frozen foods plated on M. enterococcus Agar was $70-500 \%$, assuming $100 \%$ recovery from Barnes' medium. Pavlova et al. (1972) used small inocula, $0 \cdot 1-\mathrm{ml}$ volumes of $10^{-4}$ faecal dilutions, and did not report any relative inhibition.

My findings are broadly in agreement with those of previous studies (Sabbaj et al., 1971; van der Wiel-Korstanje and Winkler, 1975). There were, however, several differences between the flora of the neonates and of the adults that have not previously been recorded. Strep. faecium was isolated from 15 of the 39 adult faeces $(38.5 \%)$ whereas it was not isolated from any of the 21 neonatal samples. Strep. bovis was more frequently isolated from the neonatal group, 5 out of 21 $(23.8 \%)$ compared with 2 out of $39(5 \%)$ for the adults. Nine of the neonatal samples produced no group D streptococci $(43 \%)$ compared with only five of the adult samples $(13 \%)$. The adult group produced a wider range of streptococci, but this may have been merely a reflection of the larger number of adult specimens examined (39:21).

In over half of the samples yielding Strep. faecalis, viable counts of the organism were within the range $10^{6}-10^{9}$ organisms per gram, whereas in the samples yielding Strep. faecium, viable counts of the organism were in all cases below $10^{6}$ organisms $/ g$, and two-thirds of samples had counts below $10^{5}$ organisms $/ \mathrm{g}$.

I acknowledge the help and advice given by $\mathrm{Dr}$ M. T. Parker and Dr C. Dulake in the preparation of this paper.

\section{References}

Barnes, E. M. (1956). Methods for the isolation of faecal streptococci (Lancefield Group D) from bacon factories. Journal of Applied Bacteriology, 19, 193-203.

Burkwall, M. K., and Hartman, P. A. (1964). Comparison of direct plating media for the isolation and enumeration of enterococci in certain frozen foods. Applied Microbiology, 12, 18-23.

Cowan, S. T., ed. (1974). Cowan and Steel's Manual for the Identification of Medical Bacteria, 2nd edition. Cambridge University Press, London.

Facklam, R. R., Padula, J. F., Thacker, L. G., Wortham, E. C., and Sconyers, B. J. (1974). Presumptive identification of group A, B, and D streptococci. Applied Microbiology, 27, 107-113.

Facklam, R. R. (1976). A review of the microbiological techniques for the isolation and identification of streptococci. CRC Critical Reviews in Clinical Laboratory Sciences, 6, 287-317.

Gross, K. C., Houghton, M. P., and Senterfit, L. B, (1975). Presumptive speciation of Streptococcus bovis and other group D streptococci from human sources by using arginine and pyruvate tests. Journal of Clinical Microbiology, 1, 54-60.

Hamilton, W. J. (1972). Streptococcal grouping: heat extraction of $\mathrm{C}$ substance from beta haemolytic streptococci. Medical Laboratory Technology, 29, 385-388.

Hewitt, J. H., and Rigby, J. (1976). Effect of various milk feeds on numbers of Escherichia coli and Bifidobacterium in the stools of newborn infants. Journal of Hygiene, 77, 129-139.

Klein, R. S., Recco, R. A., Catalano, M. T., Edberg. S. C., Casey, J. I., and Steigbigel, N. H. (1977). Association of Streptococcus bovis with carcinoma of the colon. New England Journal of Medicine, 297, 800-802. 
McIntyre, M. (1978). Detection of capsulated Haemophilus influenzae in chest infections by counter current immunoelectrophoresis. Journal of Clinical Pathology, 31, 31-34.

Medrek, T. F., and Barnes, E. M. (1962). The influence of the growth medium on the demonstration of a group $\mathrm{D}$ antigen in faecal streptococci. Journal of General Microbiology, 28, 701-709.

Niven, C. F. Jr., Smiley, K. L., and Sherman, J. M. (1942). The hydrolysis of arginine by streptococci. Journal of Bacteriology, 43, 651-660.

Parker, M. T., and Ball, L. C. (1976). Streptococci and aerococci associated with systemic infection in man. Journal of Medical Microbiology, 9, 275-302.

Pavlova, M. T., Brezenski, F. T., and Litsky, W. (1972). Evaluation of various media for isolation, enumeration and identification of fecal streptococci from natural sources. Health Laboratory Science, 9, 289-298.

Raibaud, P., Caulet, M., Galpin, J. V., and Mocquot,
G. (1961). Studies on the bacterial flora of the alimentary tract of pigs. II. Streptococci: selective enumeration and differentiation of the dominant group. Journal of Applied Bacteriology, 24, 285-306.

Sabbaj, J., Suttar, V. L., and Finegold, S. M. (1971). Comparison of selective media for isolation of presumptive group D streptococci from human feces. Applied Microbiology, 22, 1008-1011.

Van der Wiel-Korstanje, J. A. A., and Winkler, K. C. (1975). The faecal flora in ulcerative colitis. Journal of Medical Microbiology, 8, 491-501.

Williams, R. E. O. (1958). Laboratory diagnosis of streptococcal infections. Bulletin of the World Health Organisation, 19, 153-176.

Requests for reprints to: Dr C. J. Noble, Department of Medical Microbiology, King's College Hospital Medical School, Denmark Hill, London, SE5 8RX, UK.

Reports and Bulletins prepared by the Association of Clinical Biochemists The following reports and bulletins are published by the Association of Clinical Biochemists. They may be obtained from The Publishing Department, British Medical Journal (ACB Technical Bulletins), B.M.A. House, Tavistock Square, London WC1H 9JR. Overseas readers should remit by British Postal or Money Order.

SCIENTIFIC REVIEWS (price $£ 1 \cdot 00 / \$ 2.00$ each)

1 The assessment of thyroid function March 1971 F. V. FLYNN and J. R. HOBBS

2 Renal function tests suitable for clinical practice January 1972 F. L. MITCHELi, N. VEALL, and R. W. E. WATTS

3 Biochemical tests for the assessment of fetoplacental function May 1975 C. E. WILDE and R. E. OAKEY

4 Test of exocrine pancreatic function March 1977 A. H. GOWENLOCK

TECHNICAL BULLETINS (price $£ 1 \cdot 00 / \$ 2.00$ each)

22 Bilirubin standards and the determination of bilirubin by manual and technicon AutoAnalyzer methods January 1971 BARBARA BILLING, RUTH HASLAM, and N. WALD

23 Interchangeable cells for spectrophotometers and fluorimeters September 1971 S. S. BROWN and A. H. GOWENLOCK

24 Simple tests to detect poisons March 1972 B. w. MEADE $e t$ al.

25 Blood gas analysers May 1972 K. DIXoN

26 Kits for enzyme activity determination September 1972 S. B. ROSALKI and D. TARLOW

27 Assessment of pumps suitable for incorporation into existing continuous flow analytical systems November 1972 A. FLECK et al.
28 Routine clinical measurements of transferrin in human serum September 1973 K. DIXON

29 Control materials for clinical biochemistry (5tb edition) September 1973 J. F. STEVENS

30 Notes on the quality of performance of serum cholesterol assays September 1973 s. S. BROWN

31 Determination of uric acid in blood and in urine July 1974 R. W. E. WATTS

32 A survey of amino acid analysers readily available in the United Kingdom September 1974 J. E. CARLYLE and P. PURKISS

33 Definitions of some words and terms used in automated analysis November 1974 A. FLECK, R. ROBINSON, S. S. BROWN, and J. R. HOBBS

34 Measurement of albumin in the sera of patients January 1975 LINDA SLATER, P. M. CARTER, and J. R. HOBBS

35 Investigation of the validity of temperature correction factors for serum aspartate and alanine transaminases March 1975 S. B. ROSALKI et al.

36 Factors influencing the assay of creatinine November 1975 J. G. H. COOK

37 A survey of enzyme reaction rate analysers readily available in the United Kingdom July 1977 R. A. SAUNDERS and R. F. BURNS

38 Transport of specimens for clinical chemistry analysis November 1977 P. WILDING, J. F. ZILVA, and C. E. WILDE

39 A scheme for the evaluation of diagnostic kits May 1978 P. H. LLOYD 